\title{
Peluang Digunakannya Lembaga Mediasi Untuk Menyelesaikan Permasalahan Debitor Pailit
}

\author{
Lucky Dafira Nugroho \\ Fakultas Hukum Universitas Trunojoyo Madura \\ lucky.dafira@trunojoyo.ac.id
}

\begin{abstract}
In addition to the model of dispute resolution through the courts (litigation) between the debtor and creditor in the Bankruptcy and suspension of payment act, it is possible also to use the dispute resolution model non litigation (other than courts) who begins to bloom was used as response to the judiciary, and complicated. This article will focus on the utilization of the institutions in the procedure of mediation as one alternative to prevent the occurrence of bankruptcy against the debtor. From the description of the background, it can be formulated the legal issue thoroughly, namely whether it is possible to use mediation in the petition for suspension of debt payments and be an alternative to prevent bankruptcy. To answer the legal issues will be conducted legal research with this type of normative legal research. Possible existence of a model of alternative dispute resolution, such as mediation, in the peace process in bankruptcy and PKPU. However, the mediation remain bound by the provisions of the law as set forth in the Bankruptcy act and creditor quorum of such concurrent in suspension of payment in meetings of the peace, and the homologation by the supervisory judge as well as other provisions.
\end{abstract}

Keywords : Mediation, Debtor, Bankruptcy/Insolvency.

\begin{abstract}
Abstrak
Selain model penyelesaian sengketa melalui pengadilan (litigasi) antara debitor dan kreditor dalam UU Kepailitan dan PKPU, dimungkinkan juga menggunakan model penyelesaian sengketa non litigasi (diluar pengadilan) yang mulai marak dipergunakan sebagai respon atas peradilan yang lama, dan rumit. Artikel ini akan berfokus tentang pemanfaatan lembaga mediasi dalam prosedur PKPU sebagai salah satu alternatif untuk mencegah terjadinya kepailitan terhadap debitor. Dari uraian latar belakang tersebut, maka dapat dirumuskan isu hukum yang hendak di teliti yaitu apakah mediasi dimungkinkan dipergunakan dalam permohonan penundaan kewajiban pembayaran utang dan menjadi alternatif mencegah kepailitan. Untuk menjawab isu hukum tersebut akan dilakukan penelitian hukum dengan tipe penelitian hukum normatif. dimungkinkan adanya model penyelesaian sengketa alternatif, berupa mediasi, dipergunakan dalam proses perdamaian dalam kepailitan dan PKPU. Namun, mediasi tersebut tetap terikat dengan ketentuan hukum formil sebagaimana diatur dalam UU Kepailitan dan PKPU seperti kuorum kreditor konkuren dalam rapat perdamaian, dan homologasi oleh hakim pengawas serta ketentuan lainnnya.
\end{abstract}

Kata Kunci : Mediasi, Debitor, Pailit. 


\section{Pendahuluan}

Saat ini tidak dapat dipungkiri sebagian besar pelaku usaha memperoleh modal usahanya dari bank atau pihak ketiga lainnya, sehingga krisis global ini telah mengakibatkan dunia usaha atau perusahaan - perusahaan di Indonesia mengalami kesulitan untuk melanjutkan pergerakannya yang tentunya berdampak kepada ketidakmampuan dunia usaha untuk mengembalikan utang - utangnya kepada bank maupun pihak ketiga yang mengakibatkan kredit macet. Keadaan tersebut merupakan titik awal terjadinya konflik antara debitor (pengusaha) dengan para kreditornya. Menyikapi keadaan tersebut, para pengurus perusahaan terpaksa melakukan berbagai tindakan dalam rangka menyelamatkan perusahaan dan/atau aset - asetnya. Bagi perusahaan dalam perkiraan pengurusnya akan dapat membayar utang - utangnya, maka akan melakukan negosiasi kepada para kreditornya untuk dapat menunda dan menjadwalkan kembali pembayaran utangnya. Sementara, bagi perusahaan yang sudah tidak mungkin lagi membayar utangnya, maka tinggal menunggu nasib kreditor atau menjalankan pembubaran perusahaan melalui RUPS yang dilakukan atas usul direksi sesuai dengan ketentuan Pasal 144 ayat (1) Undang - undang Nomor 40 Tahun 2007 tentang Perseroan Terbatas.

Untuk mengatasi kondisi ini, langkah yang tepat untuk menyelesaikan kredit macet tersebut, baik untuk kepentingan kreditor dan debitor, adalah dengan memberikan keuntungan bagi kedua belah pihak. Banyak langkah yang dapat ditempuh untuk mengatasi permasalahan tersebut salah satunya adalah dengan mengajukan permohonan pailit. Kepailitan merupakan salah satu jalan keluar untuk menyelesaikan sengketa debitor dan kreditor. Kepailitan merupakan suatu proses dimana debitor yang mempunyai kesulitan keuangan untuk membayar utangnya dinyatakan pailit oleh pengadilan yang dalam hal ini adalam pengadilan niaga karena debitor tidak dapat lagi membayar utangnya. Aturan yang memberikan 
perlindungan hukum sebagai bentuk perwujudan keadilan tersebut tertuang pada Undang - Undang Nomor 37 Tahun 2004 tentang Kepailitan dan Penundaan Kewajiban Pembayaran Utang, Lembaran Negara Republik Indonesia Tahun 2004 Nomor 131, Tambahan Lembaran Negara Nomor 4443, yang selanjutnya disebut UU Kepailitan dan PKPU.

Atas adanya permohonan pailit ke kepaniteraan pengadilan niaga tersebut, debitor dapat mengajukan penundaan kewajiban pembayaran utang, yang selanjutnya disebut PKPU, apabila tidak dapat atau memperkirakan bahwa ia tidak akan dapat melanjutkan membayar utang utangnya yang sudah jatuh waktu sebagai reaksi atas permohonan pailit yang diajukan oleh salah satu kreditornya (vide Pasal 222 ayat (2) UU Kepailitan dan PKPU). Searah dengan upaya untuk memberikan perlindungan hukum kepada debitor terhadap tuntutan kepailitan itu, maka pada Pasal 229 ayat (3) - (4) UU Kepailitan dan PKPU diatur tentang kedudukan yang lebih dipentingkan terhadap permohonan
PKPU daripada permohonan pernyataan pailit. Dalam pasal ini disebutkan, bahwa apabila permohonan pernyataan pailit dan permohonan penundaan pembayaran utang diperiksa pada saat yang bersamaan, maka permohonan penundaan kewajiban pembayaran utang harus diputuskan terlebih dahulu.

M. Hadi Shubhan mengutarakan bahwa ada dua pola PKPU, yakni pertama, PKPU yang merupakan tangkisan bagi debitor terhadap permohonan kepailitan yang diajukan oleh kreditornya. Kedua, PKPU inisiatif sendiri debitor yang memperkirakan ia tidak mampu membayar utang - utangnya kepada kreditor (Shubhan, 2008 : 147). Merujuk uraian diatas, maka PKPU dapat dimanfaatkan sebagai sarana atau alat hukum bagi debitor untuk menjadwalkan kembali penyelesaian utangnya sekaligus mencegah kepailitan. Dalam hal ini, undang undang memberikan tempo 270 hari terhitung sejak putusan penundaan kewajiban pembayaran utang ditetapkan. Dalam pelaksanaan PKPU, sesuai dengan ketentuan 
Pasal 240 ayat (1) UU Kepailitan dan PKPU, maka debitor tidak kehilangan haknya untuk mengalihkan dan mengurus harta, asalkan dilakukan bersama - sama dengan pengurus. Kedudukan debitor seperti ini tentunya dapat memberikan keuntungan baik dari pihak debitor dan kreditor. Bagi debitor akan membuka kesempatan untuk memperbaiki dan mengatasi kesulitan likuiditsnya, sehingga usahanya dapat dipertahankan dan membayar utang - utangnya. Adapun bagi kreditor, adanya penundaan kewajiban pembayaran utang akan terbuka peluan kemungkinan utang utangnya dapat dilunasi secara penuh.

Pada hakekatnya setiap utang harus dibayar. Terhadap utang yang telah jatuh tempo, maka pelaksanaan eksekusinya dapat dilakukan atas permohonan para kreditor melalui prosedur kepailitan. Jika debitor tidak mampu membayar utangnya, maka debitor dapat dinyatakan pailit dengan tujuan dilakukan pemberesan atas harta (budel pailit). Keadaan demikian tidak selalu efektif, sedangkan apabila debitor diberi waktu, maka besar harapan debitor akan dapat melunasi utang utangnya. Dalam putusan pengadilan debitor akan diberi kesempatan untuk menunda (merestrukturisasi) pembayaran utangnya hingga batas waktu yang ditentukan secara limitatif dan atas putusan ini para pihak tidak diberi hak untuk mengajukan banding. Jadi, lembaga kepailitan adalah ultimum remedium setelah upaya - upaya yang ditempuh tidak memperoleh hasil.

Selain model penyelesaian sengketa melalui pengadilan (litigasi) antara debitor dan kreditor dalam UU Kepailitan dan PKPU, dimungkinkan juga menggunakan model penyelesaian sengketa non litigasi (diluar pengadilan) yang mulai marak dipergunakan sebagai respon atas peradilan yang lama, dan rumit. Di Indonesia dikenal beberapa model penyelesaian sengketa. Model penyelesaian sengketa tersebut terbagi menjadi dua yaitu alternatif penyelesaian sengketa (Penyelesaian sengketa diluar pengadilan) dan penyelesaian sengketa melalui pengadilan (litigasi). Penyelesaian sengketa diluar pengadilan terbagi 
atas negosiasi, mediasi, dan arbitrase. Ketiga bentuk penyelesaian sengketa tersebut dilakukan tanpa ada turut campur pengadilan dalam menyelesaikan sengketa yang terjadi. Beberapa pakar berpandangan bahwa ADR merupakan konsep yang mencakup semua bentuk atau cara cara penyelesaian sengketa didasarkan pada pendekatan konsensus atau mufakat para pihak (Rahmadi, 2010 : 11). Dengan mendasarkan pada konsep mufakat dalam mengambil keputusan yang dibantu oleh seorang mediator dimungkinkan terwujudnya keputusan yang saling memberi suatu keuntungan bagi kedua belah pihak. Keputusan yang disepakati bersama itu tidak akan menimbulkan suatu bentuk pertikaian dikarenakan tidak ada pihak yang dibuat menang ataupun kalah.

Dalam artikel ini akan berfokus tentang pemanfaatan lembaga mediasi dalam prosedur PKPU sebagai salah satu alternatif untuk mencegah terjadinya kepailitan terhadap debitor. Dari uraian latar belakang tersebut, maka dapat dirumuskan isu hukum yang hendak di teliti yaitu apakah mediasi dimungkinkan dipergunakan dalam permohonan penundaan kewajiban pembayaran utang dan menjadi alternatif mencegah kepailitan.

\section{Metode Penelitian}

Untuk menjawab isu hukum yang ada, maka akan dilakukan penelitian. Tipe penelitian dalam artikel ini adalah penelitian hukum normatif. Penelitian hukum ini akan beranjak dari pembahasan mengenai karakteristik perdamaian dalam lembaga kepailitan dan PKPU serta peluang digunakannya mediasi untuk menyelesaikan permasalahan debitor pailit. Dalam proses analisa nani akan menggunakan pendekatan konseptual dan perundang undangan. Pendekatan konseptual digunakan untuk menjabarkan mengenai konsep perdamaian dalam PKPU dan selanjutnya membandingkannya dengan konsep perdamaian dalam hukum acara perdata. Pendekatan konseptual dari perdamaian tersebut selanjutnya harus disinkronisasi dengan ketentuan dalam UU Kepailitan dan PKPU serta HIR. Hal yang sama 
dilakukan untuk mengkaji mengenai peluang digunakannya mediasi untuk menyelesaikan permasalahan debitor pailit. Bahan hukum yang digunakan antara lain literatur mengenai kepailitan dan PKPU serta mediasi. Selain itu, peraturan perundang undangan yang diperlukan antara lain UU Kepailitan dan PKPU serta PERMA 1/ 2016 tentang Mediasi di Pengadilan.

\section{Hasil dan Pembahasan}

\section{Karakteristik Perdamaian Dalam Lembaga Kepailitan Dan Penundaan Kewajiban Pembayaran Utang}

Suatu bentuk penyelesaian secara permufakatan antara pihak yang bersengketa, debitor dan kreditor, dapat di lihat dalam proses perdamaian baik dalam proses kepailitan maupun penundaan kewajiban pembayaran utang. Upaya perdamaian ini diatur dengan tegas dalam Pasal 144 - 177 UU Kepailitan dan PKPU. Dalam Pasal 144 UU Kepailitan dan PKPU disebutkan bahwa yang berhak untuk menawarkan perdamaian adalah debitor pailit. Atas penawaran perdamaian dari debitor pailit tersebut, maka kreditor dapat menerima atau menolaknya. Dari konstruksi hubungan hukum tersebut nampak bahwa perdamaian merupakan suatu bentuk penyelesaian melalui suatu kesepakatan. Penentuan kelanjutan dari penawaran perdamaian debitor pailit tersebut di tentukan atas negosiasi para pihak tanpa adanya pihak ketiga sebagai fasilitator. Hal tersebut identik dengan model penyelesaian sengketa alternatif atau non litigasi yang lebih mengedepankan suatu kesepakatan dari para pihak untuk menyelesaikan sengketa yang terjadi diantara mereka.

Perdamaian dalam hukum acara perdata biasa disebut sebagai dading. Dalam hukum acara perdata biasa yang berlaku, dading diatur dalam Pasal 130 HIR atau Pasal 154 RBg. Dading, dengan model penyelesaian sengketa mediasi dalam lingkup pengadilan negeri (peradilan umum), di wajibkan untuk ditempuh oleh para pihak atas inisiatif dari hakim pemeriksa perkara (vide Pasal 3 PERMA 1/2016 tentang Mediasi di 
Pengadilan). Hakim pemeriksa perkara dalam setiap waktu mengupayakan untuk menempuh perdamaian dengan menggunakan mediasi kepada para pihak sebelum perkara tersebut diakhiri dengan putusan akhir. Dalam melakukan mediasi untuk mencapai dading tersebut, mediator dan pihak - pihak yang bersengketa tidak terikat dengan formalitas acara dalam proses mediasi. Yang dimaksud tidak terikat dengan formalitas yang ada adalah para pihak bersama mediator dapat menentukan jadwal mediasi, tata cara, dan penentuan mediator atas kesepakatan para pihak. Tidak ada ketentuan model beracara melalui mediasi yang harus dipatuhi, dengan kata lain mediasi tersebut dibangun dengan kesepakatan para pihak dengan tidak adanya pihak lain, kecuali mediator, yang bertugas sebagai fasilitator..

Penggunaan sarana penyelesaian sengketa dengan dibantu oleh seorang mediator, atau biasa disebut mediasi, memberikan konsekuensi diimplementasikannya prinsip dan norma umum mediasi yang berlaku. Prinsip - prinsip dalam mediasi adalah privity, confidential, cepat, mudah, dan sederhana.

Ada perbedaan yang signifikan antara perdamaian dalam proses kepailitan dengan yang ada dalam hukum acara perdata biasa. M. Hadi Shubhan menunjukkan bahwa perdamaian dalam hukum acara perdata biasa tidak terikat formulanya dan dapat dilakukan sendiri oleh para pihak tanpa campur tangan pengadilan, sedangkan perdamaian dalam perkara kepailitan terjadi melalui hakim pengawas (Shubhan, 2008 : 140 - 141).

Demikian pula perdamaian dalam pemberesan harta pailit berbeda dengan perdamaian dalam PKPU. Perdamaian dalam kepailitan lebih mengarah pada proses penyelesaian utang - utang debitor melalui pemberesan harta pailit sedangkan perdamaian dalam PKPU lebih ditekankan kepada rencana penawaran pembayaran atau melakukan restrukturisasi utang (Shubhan, 2008 : 141). Proses penyelesaian utang piutang tersebut haruslah mendapat persetujuan dari hakim pengawas sehingga dimungkinkan rencana perdamaian 
yang telah disepakati oleh debitor pailit dengan kreditor tersebut ditolak. Penolakan tersebut merupakan intervensi hakim pengawas dalam penyelesaian sengketa para pihak sebagai bentuk perlindungan bagi kreditor.

Selain itu, perdamaian dalam lembaga kepailitan bukan merupakan suatu hal yang dianjurkan untuk ditempuh dan diupayakan oleh majelis hakim. Konsekuensinya bagi debitor adalah baru dapatnya ditempuh perdamaian pasca dijatuhkannya putusan pailit kepada debitor. Ratio legis penempatan upaya perdamaian atau akor setelah dijatuhkannya putusan pailit berdasarkan ketentuan dalam UU Kepailitan dan PKPU telah jelas yaitu untuk memberikan efek jera bagi debitor nakal guna tidak mengulangi perbuatannya kepada kreditur lainnya dikemudian hari. Dengan dijatuhkannya putusan pailit terlebih dahulu akan berakibat beralihnya wewenang pengurusan harta pailit kepada kurator. Hal ini untuk menghindari adanya peralihan harta miliki debitor pailit kepada pihak lain sehingga atas perbuatan tersebut ditengarai dapat merugikan para kreditor.

Upaya perdamaian dalam hukum acara perdata biasa yang tunduk pada ketentuan Pasal 130 HIR atau Pasal 154 RBg jo PERMA 1/2016, bersifat mandatory, para pihak tidak bisa menolak ataupun untuk meminta langsung dilakukannya pemeriksaan perkara secara litigasi kepada majelis hakim yang memeriksa perkara tersebut. Upaya perdamaian melalui mediasi di pengadilan tersebut sifatnya wajib untuk dilalui dan memberikan konsekuensi pada putusan akhirnya yaitu mengakibatkan putusan batal demi hukum. Konsekuensinya sangat berat dimana adanya kebatalan demi hukum putusan pengadilan manakala upaya perdamaian melalui mediasi di pengadian tersebut tidak dilalui dan diupayakan pada awal sidang oleh majelis hakim pemeriksa perkara.

Sedangkan perdamaian atau akor dalam kepailitan dan PKPU bersifat voluntary, akor dapat diajukan secara sukarela oleh debitor pailit manakala debitor pailit merasa masih mampu untuk memenuhi kewajiban kewajibannya kepada para kreditor 
(dalam keadaan solven). Adanya akor inilah yang memberikan pemikiran kepada para pembuat UU Kepailitan dan PKPU untuk meniadakan insolvency test. Oleh karena itu, manakala debitor pailit merasa masih mampu dan menghitung adanya peluang untuk tetap bertahan selanjutnya akan menggunakan akor sebagai upaya untuk mengakhiri kepailitan. Mungkin pula dalam keadaan yang sebaliknya yaitu debitor tersebut sedang berada dalam kesulitan membayar dan sampai saat ini pelaksanaan untuk pengaturan pembayaran dibantu oleh pendukung keuangan para anggota keluarga dan relasi. Hal ini jelas memberikan titik cerah bagi kreditor untuk mendapatkan hasil yang lebih besar daripada dilakukan pemberesan harta pailit.

Tabel 1.

Perbedaan Perdamaian Dalam

Hukum Acara Perdata Biasa Dengan Kepailitan Dan PKPU

\begin{tabular}{|c|c|c|}
\hline Pembeda & Hukum Acara Perdata Biasa & Kepailitan dan PKPU \\
\hline Terminologi & Dading & Accord \\
\hline Sifat & Mandatory & Voluntary \\
\hline Tempus & $\begin{array}{l}\text { Wajib ditempuh diawal sidang } \\
\text { pertama }\end{array}$ & $\begin{array}{l}\text { Dalam Kepailitan, baru dapat } \\
\text { ditempuh pasca dijatuhkannya } \\
\text { putusan pailit. } \\
\text { Dalam konteks PKPU, bisa } \\
\text { bersamaan dengan permohonan } \\
\text { PKPU. }\end{array}$ \\
\hline $\begin{array}{l}\text { Kategori } \\
\text { Model } \\
\text { Penyelesaian } \\
\text { Sengketa }\end{array}$ & Mediasi & Memiliki karakteristik tersendiri \\
\hline $\begin{array}{l}\text { Aturan } \\
\text { Hukum } \\
\text { Formil }\end{array}$ & $\begin{array}{l}\text { Pasal } 130 \text { HIR atau Pasal } 154 \\
\text { RBg jo PERMA 1/2016 }\end{array}$ & $\begin{array}{l}\text { Pasal } 151 \text {-155 dan Pasal } 281- \\
283 \text { UU Kepailitan dan PKPU }\end{array}$ \\
\hline $\begin{array}{l}\text { Tata Cara } \\
\text { Penyelesaian } \\
\text { Sengketa }\end{array}$ & $\begin{array}{l}\text { Informal, tidak terikat dengan } \\
\text { aturan mengenai tata cara } \\
\text { mediasi para pihak }\end{array}$ & $\begin{array}{l}\text { Formal, terikat dengan kuorum } \\
\text { dan substansi yang dapat } \\
\text { dibahas }\end{array}$ \\
\hline
\end{tabular}


\begin{tabular}{|l|l|l}
\hline Hasil Akhir & Akta Perdamaian & Penetapan Pengadilan \\
\hline
\end{tabular}

Sumber : Diolah dari berbagai sumber

Perdamaian dalam kepailitan

konkuren. Debitor pailit dapat bila ditelusuri terminologinya berasal mengajukan restrukturisasi utang dari bahasa Belanda yaitu accord. Di Indonesia, dalam banyak literatur belum ada keseragaman dalam penggunaan istilah perdamaian dimana ada yang menyebut "akor" (akkord), dan ada pula yang menggunakan istilah "akur”. Bila dilihat sejarahnya, hukum kepailitan yang merupakan warisan dari Belanda, maka istilah yang tepat untuk perdamaian adalah accord sebagaimana terminologi dalam bahasa Belanda. Dalam bahasa Inggris, digunakan istilah “composition" yang berarti persetujuan untuk pembayaran utang. Sedangkan dalam kamus umum bahasa Indonesia oleh W.J.S. Poerwadarminta, akor atau akur diartikan dengan cocok, sesuai, atau setuju (Porwadarminta, 1976 : 27).

Rachmadi

Usman

mengungkapkan bahwa dalam perdamaian ini, debitor pailit menawarkan pembayaran seluruh atau sebagian utang kepada kreditor kepada kreditor sebagai upaya untuk mengakhiri kepailitan, harta kepailitan yang dijual belum tentu mencukupi pelunasan sisa utang debitor pailit (Usman, 2004 : 133).

Menurut Zainal Azikin, akor atau akur (accord) dalam kepailitan diartikan sebagai suatu perjanjian perdamaian antara si pailit dengan para kreditur, dimana diadakan suatu ketentuan, bahwa si pailit dengan membayar suatu prosentase tertentu (dari utangnya), ia akan dibebaskan untuk membayar sisanya (Asikin, 2013 : 91).

Pemikiran yang sama juga diungkapkan oleh Rahayu Hartini bahwa perdamaian dalam kepailitan adalah perjanjian antara debitor pailit dengan para kreditur dimana debitor menawarkan pembayaran sebagian dari utangnya dengan syarat bahwa ia setelah melakukan pembayaran tersebut, dibebaskan dari sisa utangnya, sehingga ia tidak 
mempunyai utang lagi (Hartini, 2008 : 175).

Dari kedua kedua uraian pakar diatas yang menyebutkan bahwa perdamaian merupakan suatu perjanjian, maka untuk menentukan mengenai keabsahan perjanjian perdamaian dapat masuknya ketentuan Pasal 1320 BW dan terikat pula dengan aturan materiil sebagaimana diatur dalam UU Kepailitan dan PKPU. Oleh karena itu, untuk sahnya suatu perjanjian perdamaian haruslah memenuhi unsur - unsur seperti kesepakatan, kecakapan para pihak, obyek tertentu, dan causa yang diperbolehkan. Dalam tabel selanjutnya ini akan dibandingkan antara perjanjian perdamaian dalam kepailitan dengan PKPU dikaitkan dengan ketentuan sahnya perjanjian Pasal 1320 BW sebagai berikut :

Tabel 2.

Karakteristik Perjanjian Perdamaian Bila Dikaitkan Dengan Pasal 1320 BW

\begin{tabular}{|c|c|c|c|}
\hline \multirow{2}{*}{ No. } & \multirow{2}{*}{$\begin{array}{l}\text { Unsur - Unsur } \\
\text { Perjanjian }\end{array}$} & \multicolumn{2}{|c|}{ Perjanjian Perdamaian } \\
\hline & & Kepailitan & PKPU \\
\hline 1 & Kesepakatan & $\begin{array}{l}\text { Pasal } 151-152 \\
\text { UUK } \\
\text { yang menyatakan } \\
\text { bahwa rencana } \\
\text { perdamaian dapat } \\
\text { diterima } \\
\text { berdasarkan: } \\
\text { a. Persetujuan } \\
\text { lebih dari 1/2 } \\
\text { (satu perdua) } \\
\text { jumlah kreditor } \\
\text { konkuren diakui } \\
\text { haknya dementara } \\
\text { atau sema yang } \\
\text { diakui hui rapat } \\
\text { hadir pada rapat } \\
\text { kreditor, yang } \\
\text { bersama-sama } \\
\text { mewakili paling }\end{array}$ & $\begin{array}{l}\text { Pasal } 281 \text { ayat (1) UUK } \\
\text { yang menyatakan bahwa } \\
\text { rencana perdamaian } \\
\text { dapat diterima } \\
\text { berdasarkan: } \\
\text { a. Persetujuan lebih } \\
\text { dari 1/2 (satu perdua) } \\
\text { jumlah } \\
\text { konkuren hreditor } \\
\text { diakui atau sementara } \\
\text { diakui yang hadir } \\
\text { pada rapat kreditor } \\
\text { sebagaimana } \\
\text { dimaksud ralam } \\
\text { Pasal 268 termasuk } \\
\text { Kreditor sebagaimana } \\
\text { dimaksud dalam } \\
\text { Pasal 280, yang } \\
\text { bersama-sama }\end{array}$ \\
\hline
\end{tabular}




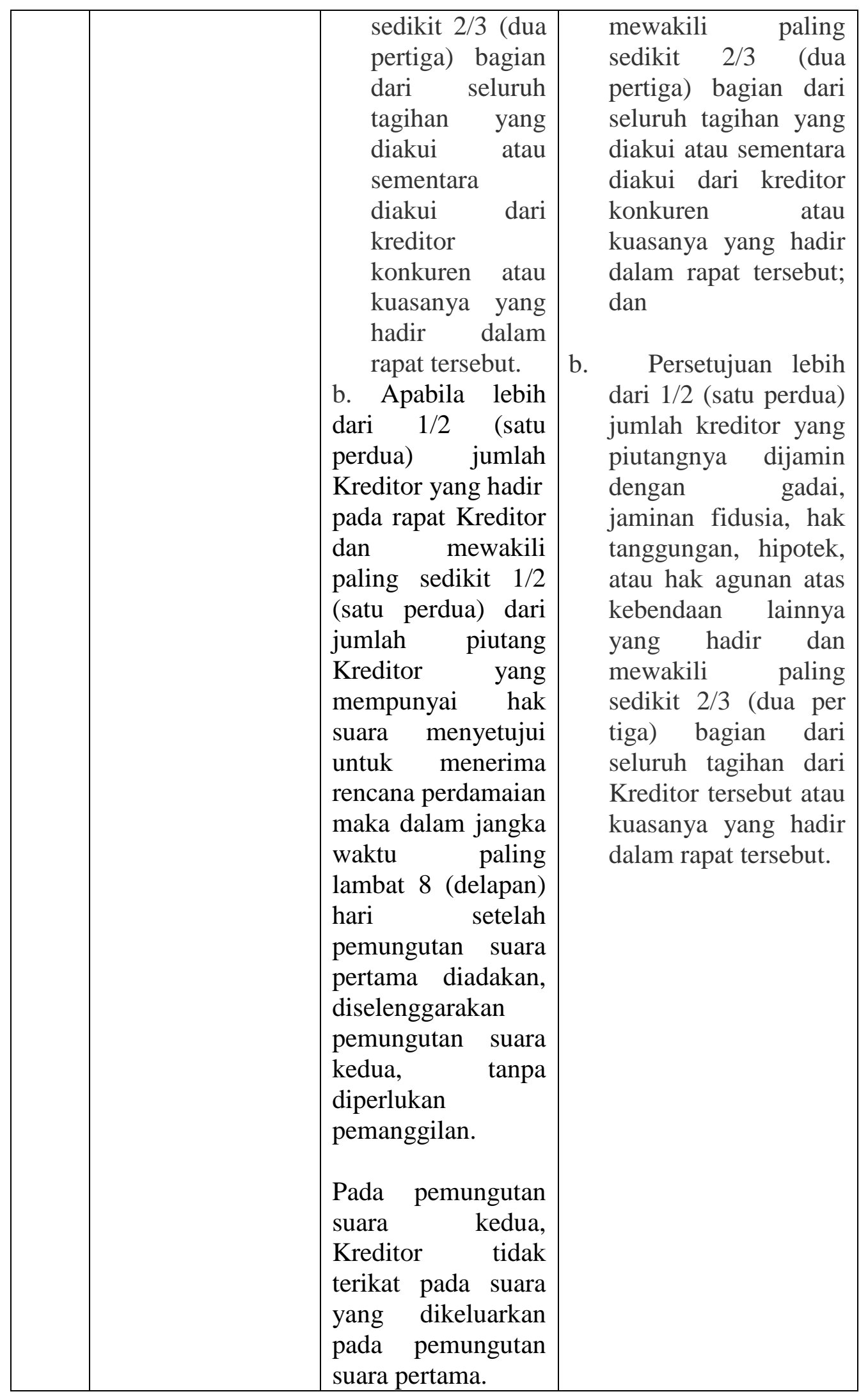




\begin{tabular}{|c|c|c|c|}
\hline 2 & $\begin{array}{l}\text { Kecakapan } \\
\text { Pihak }\end{array}$ & $\begin{array}{l}\text { 1. Debitor pailit; } \\
\text { 2. Kreditor } \\
\text { konkuren yang } \\
\text { hadir dan } \\
\text { haknya diakui } \\
\text { atau yang } \\
\text { untuk } \\
\text { sementara } \\
\text { diakui. }\end{array}$ & $\begin{array}{l}\text { 1. Debitor pailit; } \\
\text { 2. Kreditor konkuren } \\
\text { yang hadir dan } \\
\text { haknya diakui atau } \\
\text { yang untuk sementara } \\
\text { diakui; } \\
\text { 3. Kreditor Separatis. }\end{array}$ \\
\hline 3 & Obyek Tertentu & $\begin{array}{lr}\text { Penawaran } & \\
\text { pembayaran } & \text { utang } \\
\text { karena adanya } \\
\text { kemungkinan } \\
\text { kreditor } & \\
\text { mendapatkan } & \\
\text { pelunasan } & \text { utang } \\
\text { lebih } & \text { tinggi } \\
\text { daripada } & \text { bila } \\
\text { mendapatkan } & \text { dari } \\
\text { budel pailit. } & \end{array}$ & $\begin{array}{l}\text { Program rekstrukturisasi } \\
\text { utang: } \\
\text { 1. Moratorium, } \\
\text { penundaan } \\
\text { pembayaran yang } \\
\text { sudah jatuh tempo; } \\
\text { 2. Haircut, pemotongan } \\
\text { pokok pinjaman dan } \\
\text { bunga; } \\
\text { 3. Pengurangan tingkat } \\
\text { suku bunga; } \\
\text { 4. Perpanjangan jangka } \\
\text { waktu pelunasan; } \\
\text { 5. Konversi utang ke } \\
\text { saham; } \\
\text { 6. Debt forgiveness } \\
\text { (pembebasan utang); } \\
\text { 7. Bailout, pengambil } \\
\text { alihan utang; } \\
\text { 8. Write off, penghapus } \\
\text { bukuan utang. }\end{array}$ \\
\hline 4 & $\begin{array}{l}\text { Causa Yang Di } \\
\text { Perbolehkan }\end{array}$ & $\begin{array}{l}\text { Utang yang timbul } \\
\text { baik dari perjanjian } \\
\text { maupun undang - } \\
\text { undang }\end{array}$ & $\begin{array}{l}\text { Utang yang timbul baik } \\
\text { dari perjanjian maupun } \\
\text { undang - undang }\end{array}$ \\
\hline
\end{tabular}

Sumber : Diolah dari berbagai sumber

Setelah rencana perdamaian institusi pengadilan untuk tetap tersebut disetujui dalam rapat memberikan perlindungan kepada kreditur tersebut, langkah selanjutnya debitor dan kreditur hingga sengketa adalah pemeriksaan oleh hakim yang terjadi tetap dalam kerangka pengawas. Adanya hakim pengawas yang benar (going on the right tersebut merupakan upaya dari track). Dengan adanya mekanisme 
perdamaian yang ketat ini akan meminimalisir adanya upaya - upaya debitor untuk menghindari dari tanggung jawabnya secara melanggar hukum. Atas hasil rapat kreditor yang menyepakati adanya perdamaian, hakim pengawas wajib untuk memberikan penetapan disertai alasannya. Pengadilan wajib menolak pengesahan perdamaian apabila :

a) Harta debitor, termasuk benda untuk mana dilaksanakan hak untuk menahan suatu benda, jauh lebih besar daripada jumlah yang disetujui dalam perdamaian;

b) Pelaksanaan perdamaian tidak cukup terjamin dan/atau;

c) Perdamaian itu dicapai karena penipuan, atau persekongkolan dengan satu atau lebih kreditor, atau karena pemakaian upaya lain yang tidak jujur dan tanpa menghiraukan apakah debitor atau pihak lain bekerja sama untuk mencapai ini.

Hakim pengawas mungkin
menjatuhkan salah satu dari dua
bentuk penetapan yatu penolakan
atau pengesahan perjanjian

perdamaian. Atas penolakan pengadilan terhadap perjanjian perdamaian dimungkinkan diajukannya kasasi oleh kreditor yang menyetujui maupun debitor pailit. Sedangkan bila perjanjian perdamaian disahkan oleh pengadilan niaga, maka juga dimungkinkan diajukan kasasi oleh kreditor yang tidak hadir dan/atau kreditor yang menyetujui perdamaian setelah mengetahui bahwa perdamaian tersebut dicapai berdasarkan alasan sebagaiamana dimaksud dalam Pasal 159 ayat (2) huruf c.

Walaupun dalam proses pembentukan perjanjian perdamaian tersebut juga tunduk pada ketentuan Pasal 1320 BW. Akan tetapi, untuk prosedur pembatalan perjanjian perdamaian tersebut tidak dapat menggunakan mekanisme dan alasan - alasan yang ada dalam ketentuan hukum perdata biasa. Perjanjian perdamaian hanya dapat diajukan kasasi oleh pihak2 yang berkepentingan sebagaimana disebutkan diatas.

Adapun terhadap rencana perdamaian yang dihomologasi akan 
mempunyai akibat hukum sebagai berikut ;

a) Kepailitan dinyatakan berakhir;

b) Keputusan penerimaan perdamaian mengikat seluruh kreditor konkuren;

c) Perdamaian tidak berlaku bagi kreditor separatis dan kreditor yang di istimewakan;

d) Perdamaian tidak boleh diajukan untuk kedua kalinya;

e) Perdamaian merupakan alas hak bagi guarantor;

f) Hak - hak kreditor tetap berlaku terhadap garantor dan rekan debitor;

g) Hak - hak kreditor tetap belaku terhadap pihak - pihak ketiga;

h) Penangguhan eksekusi jaminan utang berakhir;

i) Actio pauliana berakhir;

j) Debitor pailit dapat direhabilitasi (Fuady, 2005 : 118 - 119).

\section{Peluang Dipergunakannya Penyelesaian Sengketa Alternatif Lain Dalam Lembaga Kepailitan Dan PKPU}

Dengan disepakatinya suatu kontrak antara kreditor dan debitor diharapkan dalam tahapan pelaksanaan kontrak senantiasa ditunaikan kewajiban masing masing sehingga tidak ada yang dirugikan. Namun, kadang kala banyak hal yang terjadi sehingga mengakibatkan debitor tidak dapat melaksanakan kewajibannya walaupun keadaan yang demikian sebenarnya tidak diharapkan oleh kedua belah pihak. Pada akhirnya tidak menutup kemunginan timbulnya sengketa antara kedua belah pihak.

Menurut Fisher dan Ury terdapat tiga faktor yang mempengaruhi penyelesaian sengketa yaitu : kepentingan (interest), hak (rights), dan status kekuasaan (power). Para pihak yang bersengketa ingin kepentingannya tercapai, hak haknya terpenuhi dan status kekuasaannya diperlihatkan, dimanfaatkan serta dipertahankan (Hernoko, 2003 : 237).

Sudah menjadi pendapat umum, khususnya di Indonesia, mengenai tidak efektif dan efisiennya proses penyelesaian sengketa melalui proses litigasi. Bahkan belakangan muncul kritik bahwa proses penyelesaian sengketa melalui peradilan tidak menjamin kepastian hukum (uncertainty), penuh kejutan dan tidak dapat diprediksi (unpredictable), buang waktu dan mahal. Bagi dunia bisnis proses yang demikian jelas akan mengakibatkan bonafiditas dan kredibilitas rendah serta ekonomi biaya tinggi (high cost 
economy). Karenanya engadilan tetap merupakan upaya ultimum remedium. Pengadilan dipandang sebagai the last resort sebagai tempat terakhir mencari kebenaran dan keadilan (Harahap, 1997 : 160).

Seperti halnya dalam penyusunan kontrak bisnis yang perlu menekankan konsep win - win solution, maka dalam hal terjadi sengketa tentunya perlu diupayakan penyelesaian yang terbaik. Suatu penyelesaian sengketa yang cepat, efektif, dan efisien. Dalam penyelesaian sengketa diantara mereka, maka penyelesaian sengketa yang terbaik dan ideal adalah pola penyelesaian win - win solution, yaitu melalui Alternative Dispute Resolution (ADR), antara lain meliputi negosiasi, mediasi, dan arbitrase. Pola ADR dipandang sebagai alternatif terbaik bagi para pihak. Melalui wadah ini keberadaan para pihak sama - sama terlindungi. Kredibilitas dan bonafiditas para pihak tetap terjaga, selain itu mengapa ADR dipandang sebagai pilihan terbaik (the best choice), adalah :

(1) Bersifat "informal";
(2) Penyelesaian secara "kooperatif" oleh para pihak;

(3) Biaya "murah" (nominal cost atau zero cost);

(4) Penyelesaian "cepat" (quick);

(5) Menyelesaikan sengketa serta memperbaiki masa depan (the future);

(6) Penyelesaian secara kompromi "compromise";

(7) Hasil yang dicapai sama sama "menang" (win - win);

(8) Hubungan semakin "mesra";

(9) "tidak antagonistik" serta tidak ada dendam;

(10) Pemenuhan secara “sukarela”(Harahap, 1997 : 160).

Menurut Goldberg dan rekan terdapat empat tujuan penyelesaian sengketa alternatif, yaitu :

- Mengurangi kemacetan di pengadilan;

- Meningkatkan keterlibatan masyarakat dan proses penyelesaian sengketa;

- Memperlancar jalur keadilan;

- Memberikan kesempatan bagi tercapainya penyelesaian sengketa yang menghasilkan keputusan yang dapat diterima oleh semua pihak (Hernoko, 2003 : 238).

Salah satu ADR yang menjadi alternatif utama adalah negosiasi. Negosiasi merupakan sarana bagi pihak - pihak untuk mendiskusikan penyelesaiannya tana keterlibatan 
pihak ketiga penengah yang tidak berwenang mengambil keputusan (mediasi), maupun pihak ketiga pengambil keputusan (arbitrase dan litigasi). Untuk itu agar penyelesaian sengketa melalui negosiasi berjalan efektif, disyaratkan :

1) Pihak - pihak bersedia bernegosiasi secara sukarela berdasarkan kesadaran yang penuh (willingness);

2) Pihak - pihak siap melakukan negosiasi (preparedness);

3) Mempunyai wewenang mengambil keputusan (authorotitaive);

4) Memiliki kekuatan yang relatif seimbang sehingga dapat menciptaka saling ketergantungan (relative equal bargaining power);

5) Mempunyai kemauan menyelesaikan masalah (willingness to settle) (Zaidun, 2002 : 230).

Dalam kerangka kontrak bisnis yang "win - win solution" seandainya terjadi sengketa. Melalui negosiasi diharapkan tercipta hubungan yang harmonis dan saling menguntungkan para pihak diantara para pihak, sehingga adanya hubungan win - win solution aan menciptakan iklim bisnis yang kondusif.
Lembaga mediasi yang dapat dipergunakan dilingkup pengadilan niaga adalah mediasi di luar pengadilan dikarenakan mediasi dipengadilan tidak wajib diupayakan berdasar aturan PERMA 1/2016. Mediasi bisa menjadi salah satu daya tarik bagi kreditor dan debitor dalam menyelesaikan sengketa permasalahan yang dihadapi dengan beberapa benefitnya.

Bila ditinjau terlebih dahulu dari terminologinya, kata mediasi berasal dari kosakat dalam bahasa Inggris yaitu, mediation. Dalam kosakata bahasa latin dikenal mediare yang artinya menjadi penengah (Kovach, 2004 : 26). Menurut Takdir Rahmadi, mediasi adalah suatu proses penyelesaian sengketa antara dua pihak atau lebih melalui perundingan atau cara mufakat dengan bantuan pihak netral yang tidak memiliki kewenangan memutus.

Dalam Black's law dictionary dikatakan bahwa mediation is private, informal dispute resolution process in which a neutral third person, the mediator, helps disputing parties to reach an agreement. The 
mediator has no power to impose a decission on the parties (Black, 1990 : 585).

Kimberlee K. Kovach
menyebutkan bahwa mediasi
merupakan negosiasi yang difasilitasi
oleh pihak ketiga yang netral. Pihak
ketiga yang berposisi netral tersebut
disebut sebagai mediator, yang
bertugas untuk membantu
menyelesaikan sengketa antara kedua
belah pihak (kreditor dan debitor)
untuk mencapai suatu kesepakatan
yang menguntungkan kedua belah
pihak.

Senada dengan kedua rumusan pengertian diatas, Rachmadi Usman mengungkapkan bahwa mediasi adalah cara penyelesaian sengketa di luar pengadilan melalui perundingan yang melibatkan pihak ketiga yang bersikap netral (non-intervensi) dan tidak berpihak (impartial) kepada pihak - pihak yang bersengketa serta diterima kehadirannya oleh pihak pihak yang bersengketa (Usman, 2013 : 98 - 99).

Mediator hanya berposisi sebagai fasilitator atau penyambung. Dengan adanya mediator tersebut akan menghindari adanya pertikaian dengan emosi karena mediasi ini dilaksanakan untuk penyelesaian sengketa bukan dalam posisi pra kontraktual. Dengan adanya mediator diharapkan adanya pertukaran informasi dan penawaran antara kreditor dan debitor lebih terbuka. Dengan adanya keterbukaan antara kedua belah pihak akan memudahkan untuk mencari suatu titk temu guna kepentingan kedua belah pihak.

Karakteristik mediasi adalah sebagai berikut :

1) Adanya intervensi dari pihak ketiga dalam penyelesaian sengketa;

2) Proses penyelesaian sengketa dilakukan dengan bantuan pihak ketiga sebagai fasilitator dan mengkoordinasikan negosiasi antara pihak yang bersengketa;

3) Intervensi dari pihak ketiga (mediator) merupakan kesepakatan para pihak dengan tidak memihak serta netral yang tidak memiliki kewenangan untuk mengambil keputusan (ajudikasi). Mediator hanya bertugas membantu para pihak yang bersengketa secara sukarela untuk mencapai suatu 


\section{kesepakatan \\ yang \\ menguntungkan kedua belah \\ pihak atas apa yang \\ disengketakan; \\ 4) Mediator akan secara aktif mengidentifikasi dan mengklarifikasi permasalahan yang menjadi sumber sengketa selanjutnya merancang dan menyepakati sejumlah solusi untuk permasalahan tersebut.}

Pemilihan lembaga mediasi sebagai sarana penyelesaian sengketa didasarkan atas beberapa pertimbangan yaitu (1) mediasi merupakan pengembangan dari negosiasi atau dengan kata lain mediasi adalah negosiasi dengan bantuan pihak ketiga yang netral (2) mediasi merupakan penyelesaian sengketa dengan mengedepankan permufakatan (3) penyelenggaraan mediasi yang tidak diatur secara rinci dalam peraturan perundang undangan sehingga memiliki keleluasaan dalam berinteraksi antara yang bersengketa dengan mediator (4) kesepakatan merupakan restrukturisasi dari kontrak yang disengketakan.
Dalam kepailitan dikenal dengan adanya prinsip transparansi. Transparansi dalam UU Kepailitan dan PKPU dapat dilihat dari adanya pemeriksaan dan pengucapan pernyataan pailit yang terbuka untuk umum, dan pencatatan dalam register umum. (vide Pasal 8 ayat (7), 13 ayat (4), dan 298 ayat (2) serta Pasal 20 UU Kepailitan dan PKPU).

Prinsip transparansi inilah yang bertentangan dengan prinsip privity dalam mediasi. Prinsip privity menghendaki tidak adanya pihak lain selain yang bersengketa untuk tahu dan turut campur dalam mediasi dimulai saat mediasi dimulai hingga pada akhirnya mencapai kesepakatan perdamaian. Atas hasil akhir mediasi berupa akta van dading tersebut juga tidak boleh diketahui oleh umum. Jelas sekali ada pertentangan dari dua prinsip perdamaian dalam kepailitan dan mediasi yaitu antara prinsip transparansi dengan privity.

Namun, pertentangan kedua prinsip tersebut tidak perlu dicemaskan karena medias masih dimungkinkan menjadi alternatif model beracara dalam proses perdamaian dalam kepailitan dan 
PKPU. Mediasi dapat dilakukan hanya untuk proses perdamaian saja karena penyelesaian secara mufakat antara pihak debitor dan kreditor hanya ada pada tahapan rapat perdamaian.

Yang dipergunakan hanyalah model beracara mediasinya saja yang memiliki karakteristik informal, bebas ditentukan oleh para pihak terkait waktu dan tempat, serta dimungkinkan substansi yang di ajukan dalam perdamaian bisa lebih dinamis. Akan tetapi, ketentuan hukum formil dalam UU Kepailitan dan PKPU terkait dengan kuorum, dan homologasi oleh hakim pengawas, serta ketentuan lain terkait dengan perdamaian baik dalam kepailitan maupun PKPU tetap mengikat debitor dan kreditor serta mediator.

\section{Simpulan}

Dapat disimpulkan bahwa dimungkinkan adanya model penyelesaian sengketa alternatif, berupa mediasi, dipergunakan dalam proses perdamaian dalam kepailitan dan PKPU. Walaupun karakteristik mediasi yang informal dan luwes sehingga memberikan efek positif dengan dimungkinkannya substansi dalam perdamaian semakin dinamis. Namun, mediasi tersebut tetap terikat dengan ketentuan hukum formil sebagaimana diatur dalam UU Kepailitan dan PKPU seperti kuorum kreditor konkuren dalam rapat perdamaian, dan homologasi oleh hakim pengawas serta ketentuan lainnnya.

\section{Daftar Pustaka}

Anisah, Siti, (2008), Perlindungan Kepentingan Kreditor dan Debitor Dalam Hukum Kepailitan di Indonesia, Yogyakarta : Total Media.

A.S. Bambang Sugeng, dan Sujayadi, (2013), Pengantar Hukum Acara Perdata, Jakarta : Kencana.

Asikin, Zainal, (2013), Hukum Kepailitan dan Penundaan Kewajiban Pembayaran Utang di Indonesia, Bandung : Pustaka Reka Cipta.

Black, Henry Campbell, (1990), Black's Law Dictionary, St. Paul Minn : West Publishing.

Fuady, Munir, (2005), Hukum Pailit Dalam Teori Dan Praktek (edisi Revisi disesuaikan dengan UU No. 37 Tahun 2004), Bandung : Citra Aditya Bakti. 
Goodpaster, Garry, (1999), Panduan Negosiasi dan Mediasi, Jakarta : Elips.

Harahap, Yahya, (2005), Hukum Acara Perdata : Tentang Gugatan, Persidangan, Penyitaan, Pembuktian, dan Putusan Pengadilan, Jakarta : Sinar Grafika.

, (1997), Beberapa Tinjauan

Tentang Permasalahan Hukum (buku kesatu), Bandung : Citra Adity Bakti.

Hartini, Rahayu, (2008), Hukum Kepailitan, Malang : UMM Press.

Hoff, Jerry, (1998), .Indonesian Bankruptcy Law, Jakarta : Tatanusa.

Huizink, J.B., (2004), Insolventie, alih bahasa : Linus Doludjawa, Jakarta : Penerbit Pusat Studi Hukum dan Ekonomi Fakutas Hukum UI.

Kovach, Kimberlee K., (2004), Mediation : Principles And Practice, St. Paul Minn, West Publishing.

Porwadarminta, W.J.S. Kamus Umum Bahasa Indonesia, PN Balai Pustaka, Jakarta, 1976.

Rahmadi, Takdir, (2010), Mediasi : Penyelesaian Sengketa Melalui Pendekatan Mufakat, Jakarta : Raja Grafindo Persada.

Shubhan, M. Hadi, (2008), Hukum Kepailitan : Prinsip, Norma, dan Praktik di Peradilan, Jakarta : Kencana.

Sinaga, Valerie Selvie (ed.), (2005), Analisa Putusan Kepailitan pada Pengadilan Niaga Jakarta, Jakarta : Fakultas Hukum Universitas Katolik Atmajaya.

Soemartono, Gatot, (2006), Arbitrase dan Mediasi di Indonesia, Jakarta : Gramedia Pustaka Utama.

Sunarmi, (2010), .Hukum Kepailitan (Edisi 2), Jakarta : Sofmedia.

, (2010), Prinsip Keseimbangan Dalam Hukum Kepailitan di Indonesia, Jakarta : Sofmedia.

Sutantio, Retnowulan dan Iskandar Oeripkartawinata, (2009), .Hukum Acara Perdata dalam Teori dan Praktek, Bandung : Mandar Maju.

Suyatno, R. Anton, (2012), Pemanfaatan Penundaan Kewajiban Pembayaran Utang sebagai Upaya Mencegah kepailitan, Jakarta : Kencana.

Syahdeni, Sutan Remy, (2004), Hukum Kepailitan Memahami Faillissementverordening Juncto Undang - Undang Nomor 4 Tahun 1998, Jakarta : Pustaka Utama Grafiti.

(2010), Hukum Kepailitan : Memahami Undang - Undang Nomor 37 Tahun 2004 tentang kepailitan, , Jakarta : Pustaka Utama Grafiti. 
Usman, Rachmadi, (2004), Dimensi Hukum Kepailitan di Indonesia, Gramedia Pustaka Utama : Jakarta.

, (2013), Pilihan Penyelesaian Sengketa di Luar Pengadilan, Bandung : Citra Aditya Bakti.

-------, (2012), Mediasi di Pengadilan Dalam Teori Dan Praktek, Jakarta : Sinar Grafika.

Widjaja, Gunawan, (2001), Alternatif Penyelesaian Sengketa, Jakarta : Raja Grafindo Persada.

\section{Jurnal / Makalah}

Hernoko, Agus Yudha, Prinsip Prinsip Negosiasi Dalam Kontrak Bisnis, Yuridika, Vo. 18 No. 3, Mei - Juni 2003.

\section{Zaidun, M., Mekanisme Alternatif Penyelesaian Sengketa (MAPS), Diklat Manajemen dan Hukum Perdagangan Bagi Konsultan Hukum dan Pengusaha, diselenggarakan atas kerja sama Ditjen PDN Depperindag, Kanwil Depperindag Prov. Jawa Timur dengan Zaidun \& Partners Law Firm, Hotel Sahid, Surabaya, 18 November - 10 Desember 1998.}

\section{Peraturan Perundang - undangan}

Burgerlijk Wetboek vor Indonesie (BW)

Herziene Indonesisch Reglement (HIR)
Reglement Burgerlijke Rechstverordening ( $\mathrm{RBg})$

Undang - undang No. 37 Tahun 2004 tentang Kepailitan dan Penundaan Kewajiban Pembayaran Utang, Lembaran Negara Republik Indonesia Tahun 2004 Nomor 131, Tambahan Lembaran Negara Republik Indonesia 4443

Peraturan Mahkamah Aguung Nomor 1 Tahun 2016 tentang Prosedur Mediasi di Pengadilan 